Jnl. Soc. Pol. (2022), 1-21 (C) The Author(s), 2022. Published by Cambridge University Press. This is an Open Access article, distributed under the terms of the Creative Commons Attribution licence (https:// creativecommons.org/licenses/by/4.0/), which permits unrestricted re-use, distribution, and reproduction in any medium, provided the original work is properly cited. doi:10.1017/S0047279421000908

\title{
What Curbs Social Investment? The Effect of Foreign Electoral Outcomes on Childcare Expenditure Levels
}

\author{
SIMONE TONELLI (iD \\ SOCIUM Research Centre on Inequality and Social Policy, University of Bremen, Bremen, \\ Germany Mary-Somerville-Straße 9 28359, Bremen \\ email: simone.tonelli@uni-bremen.de
}

\begin{abstract}
This study aims to deepen our understanding of social investment expansion proposing a political learning mechanism to link existing institutional and political explanations. When resources are limited, increased spending in social investment often comes at the expense of politically costly retrenchment of established social insurance policies. Previous studies suggest that this trade-off results in existing entitlements crowding out new policies, and that party ideology plays less of a role in determining social policy expansion. I argue that this is because parties face an electoral dilemma, as individual preferences for social investment and social insurance have been shown to differ between groups that partly overlap in their voting behaviour. Applying a policy diffusion framework to the analysis of childcare expenditure, this study proposes that policymakers learn from the political consequences of past decisions made by their foreign counterparts and update their policy choice accordingly. The econometric analysis of OECD data on childcare expenditure shows that governments tend to make spending decisions that follow those of ideologically similar cabinets abroad and that left-wing governments with a divided electorate tend to reduce childcare expenditure if a previous expansionary decision of a foreign incumbent is followed by an electoral defeat. The findings have implications for the study of the politics of social policy development.
\end{abstract}

Keywords: childcare; comparative politics; policy diffusion; political learning; social investment; spatial econometrics

\section{Introduction}

The transformations associated with the shift to a post-industrial society gave rise to a set of new social risks (NSRs) more heterogeneous than those generated in industrial economies, and hence more difficult to compensate for via social insurance (Bonoli, 2005; Esping-Andersen, 2002; Armingeon and Bonoli, 2007). Instead, NSRs are tackled by a measure of social investment, such as active labour market policies and childcare services (Morel and Palier, 2011). Social investment policies are thus considered important instruments to confront the risks generated by post-industrial societies, and the slow development of these services is puzzling (Bouget et al., 2015). 
This research adopts a policy diffusion perspective and proposes a political learning mechanism through which the consequences of the politics of social investment can both facilitate and hamper the development of these policies. In this framework, policymakers are assumed to be Bayesian learners whose beliefs about the consequences of a policy adoption are updated when new information is gathered (Braun and Gilardi, 2006; Tversky and Kahneman, 1974). It is argued that information about the political success or failure of a policy decision in other jurisdictions is expected to affect policymakers' judgments about the political feasibility of a given policy proposal altering their policy choice (May, 1992).

The central argument is developed around the electorally uncertain character of the politics of social investment expansion. Social investment policies are not supported equally by all individuals in a polity. NSR groups are more likely to prefer an emphasis on expenditures that allow them to participate in the labour market, while already integrated individuals, such as production workers with specific skills, are more likely to prefer compensation for 'old risks' (Häusermann, 2010; Häusermann et al., 2014; Häusermann et al., 2019). Overall, people are more likely to oppose the expansion of benefits from which they do not directly benefit (Busemeyer et al., 2015; Busemeyer and Neimanns, 2017; Busemeyer and Garritzmann, 2017; Chung and Meuleman, 2017).

Even though individuals belonging to different social groups have, on average, different preferences for social policy, their party preferences are not always as different (Häusermann and Kriesi, 2015). In this study, it is argued that incumbents whose electorate is divided on which policy to prioritise face a political dilemma. Indeed, in times of austerity, part of the electorate of governing parties may perceive the expansion of social investment as a shift of resources from the protection for old risks and translate this into a loss of support. Thus, uncertain of the political outcome of their policy choice, the decisions of parties in government may be informed by the past experience of their foreign counterparts in an attempt to learn from their electoral consequences and reduce political risks.

To test this argument, I estimate the association between the domestic and foreign levels of childcare expenditure, where the past foreign policy decisions are weighted by their closest electoral outcomes. The policy change under study is the level of expenditure in childcare services, as family policy is a key element of the social investment approach, which emphasises investments in children's social and cognitive skills (Esping-Andersen, 2002) and removes a major obstacle to mothers' labour market integration (Lewis et al., 2008; Hook, 2015; Esping-Andersen, 2009).

The electoral relevance of childcare services and other work-friendly family policies has been growing together with the declining importance of the core constituencies of mainstream parties, generally more in favour of 
male-breadwinner social insurance policies, such as industrial workers for the parties of the Left and religious voters for centre parties (Schwander et al., 2018). Promoting social investment, these parties attempt to attract new voters, such as women and young highly educated professionals (Morgan, 2013; Karreth et al., 2013; Häusermann, 2018; Schwander and Häusermann, 2013). Under different circumstances, these electoral strategies have proven able to produce both electoral rewards and sanctions (Abou-Chadi and Wagner, 2019; Nelson and Giger, 2019; Neimanns, 2021).

The organisation of the paper will start with a section outlining the theoretical mechanism through which political learning is expected to influence an incumbent policy choice. This is followed by a section on the politics of social investment that contains an illustration of the electoral dilemma faced by governments with a divided electorate and formalises testable hypotheses on the effect of political learning. The subsequent sections describe the research design and empirical strategy, present and discuss the findings, and the final section concludes.

\section{Learning from Foreign Electoral Consequences: A Mechanism of Policy Diffusion}

Policy diffusion occurs when government policy decisions in one country are systematically conditioned by prior policy choices made in other countries (Simmons et al., 2006). There is a widespread consensus on three broad classes of diffusion mechanisms: learning, emulation, and competition (Braun and Gilardi, 2006; Simmons et al., 2006; Shipan and Volden, 2008; Graham et al., 2013; Gilardi, 2012). In this study, learning from the consequences of other units is proposed as a mechanism to explain the slow development of social investment.

Learning can be defined as the process of acquisition of new relevant information that permits the updating of beliefs about the effects of a new policy (Meseguer, 2004; Meseguer, 2005; Meseguer, 2003; Braun and Gilardi, 2006). The learning process is best described in terms of Bayesian updating. Individuals update their beliefs by looking at the experiences of others, either rationally or relying on 'cognitive shortcuts' such as representativeness, availability and anchoring (Tversky and Kahneman, 1974; McDermott, 2001; Weyland, 2012; Weyland, 2009).

The acquisition of new relevant information can lead to two forms of learning. Policy learning occurs when the information acquired concerns the effectiveness of a policy, i.e. when it achieves what it is designed to do (Meseguer, 2003). Political learning occurs when the information acquired concerns the payoffs associated with policies, i.e. their electoral rewards and their closeness to the policymaker ideal point (Braun and Gilardi, 2006, p. 301). 
The focus of this paper is on political learning, i.e. 'judgments about the political feasibility of policy proposals and understandings of the policy process within a given policy domain' (May, 1992, p. 339). Examples of political learning are political actors adapting their political strategies to advance their political agendas without suffering severe electoral costs (Pierson, 1994), e.g. proposing fewer radical reforms and negotiating with interest groups to achieve reforms (Natali, 2002).

The scholarship on policy diffusion is regarded as the field of study that has done the most to link theoretical models of learning to empirical analyses (Dunlop and Radaelli, 2013, p. 600), developing models that included both mechanisms of policy and political learning (Braun and Gilardi, 2006; Gilardi and Wasserfallen, 2019). Empirically, this research showed the importance of political learning as a mechanism influencing many policy developments. Policy diffusion is often conditional on ideological ground, as political/ideological proximity between units facilitates diffusion (Volden, 2006; Butler et al., 2017), and public opinion support (Pacheco, 2012; Pacheco and Maltby, 2017; Abel, 2019). Governments also react to the electoral consequences of the prior policy choices of other countries (Gilardi, 2010) and tend to reframe diffusing laws in more electorally acceptable forms (Mallinson and Hannah, 2020).

Research in party politics has shown that political learning also occurs between parties, which strategically adjust their ideological orientations according to the shifts of their counterparts that have recently governed (Williams, 2015; Williams and Whitten, 2015). Parties also adjust their positions according to shifts in public opinion when the direction of change is clearly disadvantageous for the party (Adams et al., 2004). A growing amount of research in the intersection between party politics and policy diffusion is collecting evidence that this phenomenon takes place also cross-nationally (Böhmelt et al., 2017; Böhmelt et al., 2016; Schleiter et al., 2021; Adam and Ftergioti, 2019). Ideological shifts, however, do not come without a cost. Voters update their party support accordingly and hold governing parties accountable for their policy outputs (Adams et al., 2020; Bernardi and Adams, 2019; Adams et al., 2006).

Figure 1 contains a stylised model of political learning via foreign electoral consequences. Let $i$ be a country in which the government must decide how to allocate the yearly budget for social expenditure, let $j$ be a country that recently had a national election, and let the government of the two countries have similar constituencies. The way government in country $i$ will allocate social expenditure will depend on a number of domestic factors, such as its ideological orientation, the existence of a specific problem pressure, and the availability of sufficient resources. There will also be, however, non-domestic factors affecting the government decisions via policy or political learning. One form of political learning occurs when the government in country $i$ observes the outcome of the election in 


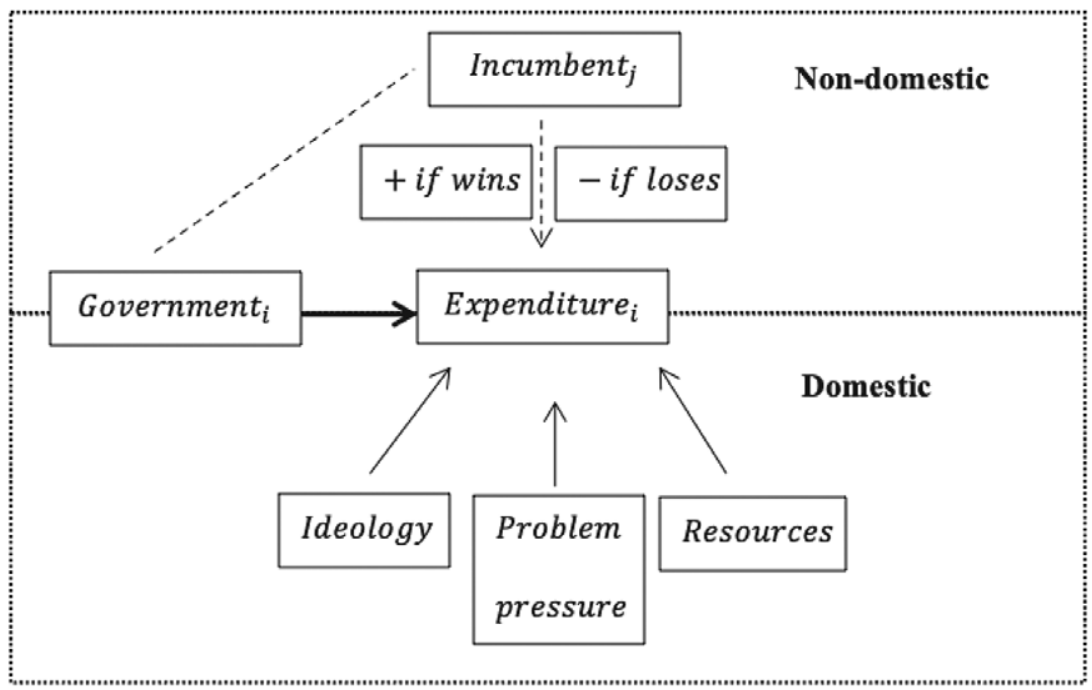

FIGURE 1. Model of political learning via electoral consequences

country $j$ (dashed line) and updates its perception of adequacy of a given policy choice accordingly. In this way, the expenditure decision in country $i$ is affected by the electoral outcome of country $j$ (dashed arrow). More specifically, if the incumbent in country $j$ wins the election, the government in country $i$ will be more likely to make similar policy decisions; if the government in country $j$ loses the election the government in country $i$ will be less likely to make similar policy decisions.

The model of political learning in figure 1 relies on the assumption that the learning government is uncertain of the optimal course of action to undertake. This is not, however, always the case. The next section elaborates on the reasons why social investment expansion may be considered a source of uncertainty and the conditions under which such uncertainty may occur.

\section{The Uncertain Politics of Social Investment}

Unconstrained public opinion support for social investment is broad (Garritzmann et al., 2018) but is significantly reduced when its expansion has to be financed through cuts in existing entitlements (Busemeyer et al., 2015; Busemeyer and Garritzmann, 2017). In times of austerity, the expansion of some programs tends to occur at the expense of others (Häusermann, 2010), and social insurance programs compete with needs-based benefits (Palier, 2010; Palier and Thelen, 2010; Emmenegger et al., 2012; Kim and Choi, 2020).

As a consequence, the political conflict in advanced political economies is characterised by friction between individual preferences for policies that 
distribute benefits on the basis of contributions and those that do so on the basis of need (Beramendi et al., 2015), and preferences between expenditure that generates immediate consumption for the insured and expenditure whose returns are diffused and delayed, such as active labour market policies, investments in human capital and child and elderly care services (Häusermann and Kriesi, 2015; Rueda, 2005; Schwander and Häusermann, 2013; Van Lancker, 2013).

Individuals with different preferences for social policy, however, do not necessarily vote for different parties (Häusermann and Kriesi, 2015). On the one hand, part of the electorate of the Left opposes increasing spending on social investment if it perceives it as a threat to existing entitlements (Abou-Chadi and Wagner, 2019). On the other hand, the same parties are rewarded for the expansion of certain social investment policies, i.e. childcare (Nelson and Giger, 2019), but only from individuals further up the income distribution, i.e. those more likely to make use of them (Neimanns, 2021).

I argue that a divided electorate and the unpredictability of electoral returns of a social investment expansion generate uncertainty in the decision-making process of policymakers lacking complete information about what is the optimal course of action to undertake. To overcome information deficits, governments may look at the experiences of others and learn from their consequences (Braun and Gilardi, 2006; Meseguer, 2004).

Therefore, when cabinets allocate more resources to childcare expenditure and are rewarded in subsequent elections, the other countries' expenditure levels should increase ( $\left.\mathrm{H}_{1}\right)$. Similarly, when cabinets allocate more resources to childcare expenditure and are sanctioned in subsequent elections, the other countries' expenditure levels should decrease ( $\left.\mathrm{H}_{2}\right)$.

Political learning, however, should occur only in situations of uncertainty. To be valid, the hypotheses above should fulfil two conditions: first, there must be a divided electorate, i.e. groups of individuals prioritising, on average, different social expenditures, and voting, on average, for the same party; second, the divided electorate should be the electorate of the governing parties.

Thus, as a first scope condition (SC1), the effect should be significant only in countries in which the size of groups more in favour of social insurance is declining in favour of groups with a preference for social investment (Schwander et al., 2018). Low-skilled workers with specific skills are especially likely to oppose investment-oriented policies (Häusermann, 2010; Häusermann et al., 2014) while high-skilled and female labour market outsiders strongly favour social investment policies (Häusermann et al., 2014). The welfare priority of these groups is even stronger when the relative importance of social insurance or social investment is included in the picture: Production workers prioritise social insurance and social consumption more than every other category, while high skilled socio-cultural professionals are the most positive towards social investment (Häusermann et al., 2019). Therefore, the effect of the foreign political 
consequences should be stronger in countries where the ratio between socio-cultural professionals and production workers is skewed in favour of socio-cultural professionals and weaker where the ratio is skewed in favour of production workers (SC1).

A second scope condition is that the governing party or coalition should have a divided electorate. The majority of social democratic parties balance their programmatic offer between social investment and protection for old risks (Häusermann et al., 2019), arguably reflecting the evidence that socio-cultural professionals and production workers do not significantly differ in their probability of voting parties on the Left (Häusermann and Kriesi, 2015). Indeed, an expansion of childcare services increases the electoral support for the Left only in the part of its electorate with higher income, generally socio-cultural professionals (Neimanns, 2021). This implies that the electorate of the parties of the Left is the most divided on these policy preferences. Conversely, the electorate of Christian democratic and Centre-right parties is also changing as the religious voters are losing importance, and these parties may compete for centrist voters embracing more progressive views on childcare, especially when a radical-right competitor is missing (Schwander et al., 2018; Fleckenstein, 2011). In contrast, far-right parties are not expected to shift their positions on childcare to follow public opinion shifts, as they are generally sanctioned by a more resilient electorate (Adams et al., 2006). Therefore, while all parties on the ideological spectrum but the far-right may be to an extent susceptible to the foreign electoral consequences of childcare expansion, the effect should be stronger for the parties on the Left (SC2).

\section{Data and Methods}

To test the hypotheses stated in the previous section, I model the diffusion effects with the inclusion of spatial lags in the model specification, relying on a longitudinal dataset with observations for 23 OECD countries ${ }^{1}$ from 1999 to 2013. The dependent variable is the total public and mandatory private social expenditure for childcare and early education services as a percentage of GDP (OECD, 2018b). The restriction of the sample size to 23 countries is due to data availability of the same countries in the European Social Survey Cumulative File (ESS, 2018), and the time frame is given by data availability for all 23 countries at the time of analysis.

Data on election dates, election outcomes and cabinet composition for the definition of the weighting matrices are taken from Döring and Manow (2019). Government positions on the ideological dimension are measured on a left-right scale from 1 to 10 . It is calculated by averaging the position of the cabinet parties, weighted by the number of seats occupied, using expert survey data (Döring and Manow, 2019). I use ESS (2018) waves 1-8 to measure the size of production 
workers (PW) and socio-cultural professionals (SCP) according to Oesch's (2006) class schema. Each individual is assigned to one category according to their ISCO-code and then categories are aggregated by country and wave. Since the waves are published every two years and the survey is conducted in the years in between, the values of a wave done at year $t$ are imputed to the years $t-1, t-2 \ldots t-n$ if values are missing. For example, the values of the first wave that took place in 2002 are assumed as valid also for 1999, 2000 and 2001 . The ratio between socio-cultural professionals and production workers (SCP-to-PW ratio) is calculated dividing the share of socio-cultural professionals by the share of production workers.

The model includes several variables that are expected to influence the outcome of interest (see Table A1 for an overview of the variables included in the model).

Theoretically, the level of childcare expenditure in a year is likely to depend on the level of the previous year, thus I include the lagged value of the dependent variable. Methodologically, whether the lagged dependent variable (LDV) should be included or not in the model specification, even when part of the data generating process, is an open debate. While LDV models are known to produce biases in the estimation of coefficients (Achen, 2000; Plümper et al., 2005), it has been argued that there is nothing pernicious in using it when the time dimension is large enough $(T \geq 15)$ (Beck and Katz, 2011). Furthermore, the omission of LDV would itself produce severe omitted variable bias (Wilkins, 2018), especially in the spatial specification where the LDV controls for important common trends between cross-sections that may lead to spatial patterns (Plümper and Neumayer, 2010).

Childcare expenditure levels are expected to depend on the amount of resources available in a country; to control for economic performances I include the log of the GDP per capita (World Bank, 2019b) and real GDP growth (OECD, 2018a). To control for the sociodemographic demand of childcare, the models include the total fertility rate (World Bank, 2019c) and the female labour force participation rate (World Bank, 2019a). A larger share of women in the legislative chamber (Armingeon et al., 2019) may also be associated with higher levels of expenditure, as female MPs are assumed to be more responsive to working women interests (Bonoli and Reber, 2010). I include the level of government expenditure in social security transfers as a percentage of GDP (OECD, 2018b) as it may negatively affect childcare expenditure due to the crowding out effect (Bonoli and Reber, 2010; Kim and Choi, 2020). I control for the government's ideology as parties on the Left are expected to be associated with higher levels of expenditure that promotes the participation of women in the labour market (Korpi, 2000). I include a spatial lag of geographic proximity as neighbouring countries represented in national media are known to affect family policy development (Linos, 2013) and to control for other exogenous 
shocks and common trends (Plümper and Neumayer, 2010). Finally, I include country dummies to control for all the country-specific time-invariant unobserved heterogeneity that may be associated with changing expenditure.

\section{Model specification}

I estimate a series of dynamic spatial autoregressive models (Franzese and Hays, 2007, 2008), which allow for dependence between observations due to strategic interaction as a consequence of political learning. In this analysis, the level of expenditure of one country at time $t$ is modelled as a function of the average level of expenditure on other countries at $t-1$, weighed by different attributes discussed in the following section.

In equation 1 , a weighting matrix specifies the set of countries and the relevant linkages between the countries. Accordingly, the spatial lag model is defined as:

$$
y_{t}=\varphi y_{t-1}+\beta X_{t-1}+\rho W y_{t-1}+\varepsilon
$$

Where $y_{t}$ is the dependent variable (childcare expenditure at time $t$ ), $y_{t-1}$ signifies the temporally lagged dependent variable (childcare expenditure at time $t-1), X_{t-1}$ is a matrix of temporally lagged explanatory variables. $W y_{t-1}$ stands for the product of the connectivity matrix $W$ and the lagged value of the dependent variable $y_{t-1}$, i.e. $W y_{t-1}$ is the spatial lag and $\rho$ is the corresponding spatial autoregressive coefficient.

In panel analysis, the connectivity matrix $W$, is given by a NT $\times N T$ matrix with $T(N \times N)$ sub-matrices along the block-diagonal, with an element $w_{i j}$ capturing the relative connectivity of unit (country) $j$ to unit (country) $i$ and with the diagonal elements $w_{i i}=0$. A common way to define the spatial lag is to use the temporally lagged values of the dependent variable (Gleditsch and Ward, 2008).

A common estimator is the ordinary least square (OLS) regression (Böhmelt et al., 2016; Williams, 2015; Williams and Whitten, 2015). However, the spatial lag in OLS introduces endogeneity in the specification, and maximum likelihood (ML) and two-stage least square (2SLS) have been shown to provide superior estimates and more accurate standard errors (Franzese and Hays, 2007; Plümper and Neumayer, 2010). As suggested by Anselin et al. (2008), ML may also be a way to deal with the endogeneity induced by the LDV (Elhorst, 2014).

\section{Operationalisation of country linkages}

For the operationalisation of country interdependencies, I rely on four distinct weighting matrices. Matrix $W_{\text {won }}$ captures the interdependencies between the government in country $i$ and the incumbent in country $j$, and the strength of the relationship is given by the share of parties in the incumbent coalition who 
were also part of the newly appointed cabinet after the elections. Thus, the government in country $i$ gives more weight to the decisions of its successful counterparts. $W_{\text {lost }}$ captures the interdependency between the government in country $i$ and the incumbent in country $j$ and the strength of the relationship is given by the share of parties of the incumbent coalition that were not part of the newlyappointed cabinet after the elections. Thus, the government in country $i$ gives more weight to the decisions of its unsuccessful counterparts. $W_{\text {ideo }}$ captures the ideological distance between the government in country $i$ and the government in country $j$ - that is to say, the government in country $i$ gives more weight to decisions made by more ideologically similar counterparts. Finally, $W_{\text {geo }}$ captures the geographical distance between country $i$ and $j$, so the government in country $i$ weights more decisions made by governments in proximate countries.

Each element $w_{i j}$ of the underlying connectivity matrix $W_{\text {won }}$ receives a value $0 \leq w_{i j} \leq 1$, equal to the share of parties of an incumbent cabinet coalition in country $j$ that were part of the cabinet coalition that followed the elections. Each element $w_{i j}$ of $W_{\text {lost }}$ receive a value $0 \leq w_{i j} \leq 1$, equal to the share of parties of the incumbent cabinet coalitions that were not part of the cabinet coalition that followed the elections. Each element $w_{i j}$ of $W_{i d e o}$ receives a value $1 \leq w_{i j} \leq 10$, equal to the absolute difference between the values of the left-right positions of the governments in country $i$ and $j$. Finally, each element $w_{i j}$ of $W_{\text {geo }}$ takes a value equal to the inverse distance between the capitals of country $i$ and $j$.

It is common practice to row standardize the proximity matrices to facilitate the interpretation of results, removing dependence on the scale factor and avoiding singularity, so that each row sums up to 1 . Row-standardization generates spatial lags that are a weighted average of the values of the dependent variable with weights dependent on the existence and strength of a postulated network tie between a pair of cases. The spatial lags $W y_{\text {won }}, W y_{\text {lost }}, W y_{\text {ideo }}$ and $W y_{\text {geo }}$ are calculated by multiplying the relative weighting matrices with a vector containing the time-lagged value of childcare expenditure, the resulting vector represents the average value of childcare expenditure of the countries in the sample, corrected by the weights specified in the weighting matrices.

\section{Findings}

Table 1 contains the estimated parameters. Unsurprisingly, a large part of childcare expenditure depends on the level of expenditure in previous years across all models. Besides that, the strongest predictor in model 1 is the total fertility rate: a one unit increase in the TFR is associated with a rise in expenditure by 0.09 percent of the GDP. The log of GDP per capita has a very small association with the level of childcare expenditure, such that it becomes indistinguishable from zero when further controls are included in the model specification. The level of expenditure for social security transfer as a share of GDP has a consistent 
TABLE 1. Spatiotemporal autoregressive models (Maximum likelihood estimates).

\begin{tabular}{|c|c|c|c|c|c|c|}
\hline VARIABLES & $\begin{array}{c}(1) \\
\text { Model } 1\end{array}$ & $\begin{array}{c}(2) \\
\text { Model } 2\end{array}$ & $\begin{array}{c}(3) \\
\text { Model } 3\end{array}$ & $\begin{array}{c}(4) \\
\text { Model } 4\end{array}$ & $\begin{array}{c}(5) \\
\text { Model } 5\end{array}$ & $\begin{array}{c}(6) \\
\text { Model } 6\end{array}$ \\
\hline Childcare expenditure $_{\mathrm{t}-1}$ & $\begin{array}{c}\mathbf{0 . 8 6 4} \\
(0.026)\end{array}$ & $\begin{array}{c}0.847^{* * * *} \\
(0.028)\end{array}$ & $\begin{array}{c}\mathbf{0 . 8 4 6} \\
(0.028)\end{array}$ & $\begin{array}{c}\mathbf{0 . 8 4 4} \\
(0.028)\end{array}$ & $\begin{array}{c}0.806^{* * *} \\
(0.030)\end{array}$ & $\begin{array}{c}0.801^{* * * *} \\
(0.030)\end{array}$ \\
\hline Log GDP per capita ${ }_{t-1}$ & $\begin{array}{l}\mathbf{0 . 0 4 4} \\
(0.019)\end{array}$ & $\begin{array}{l}0.037^{* *} \\
(0.018)\end{array}$ & $\begin{array}{c}0.054^{* *} \\
(0.023)\end{array}$ & $\begin{array}{c}0.036 \\
(0.023)\end{array}$ & $\begin{array}{c}0.005 \\
(0.025)\end{array}$ & $\begin{array}{c}0.008 \\
(0.025)\end{array}$ \\
\hline Female labour force $t_{t-1}$ & $\begin{array}{c}0.001 \\
(0.002)\end{array}$ & $\begin{array}{c}0.000 \\
(0.002)\end{array}$ & $\begin{array}{c}0.001 \\
(0.002)\end{array}$ & $\begin{array}{c}0.001 \\
(0.002)\end{array}$ & $\begin{array}{c}0.001 \\
(0.002)\end{array}$ & $\begin{array}{c}0.001 \\
(0.002)\end{array}$ \\
\hline GDP growth ${ }_{t-1}$ & $\begin{array}{c}-0.001 \\
(0.001)\end{array}$ & $\begin{array}{l}-0.001 \\
(0.001)\end{array}$ & $\begin{array}{c}-0.001 \\
(0.001)\end{array}$ & $\begin{array}{l}-0.000 \\
(0.001)\end{array}$ & $\begin{array}{c}0.000 \\
(0.001)\end{array}$ & $\begin{array}{l}-0.000 \\
(0.001)\end{array}$ \\
\hline Total fertility rate ${ }_{t-1}$ & $\begin{array}{c}\mathbf{0 . 0 8 6} 6^{* *} \\
(0.035)\end{array}$ & $\begin{array}{c}\mathbf{0 . 0 8 2} \\
(0.035)\end{array}$ & $\begin{array}{c}\mathbf{0 . 0 8 2}{ }^{* *} \\
(0.035)\end{array}$ & $\begin{array}{c}\mathbf{0 . 1 0 2} \\
(0.035)\end{array}$ & $\begin{array}{l}\mathbf{0 . 0 8 6} 6^{* * *} \\
(0.035)\end{array}$ & $\begin{array}{l}\mathbf{0 . 0 8 9} \\
(0.035)\end{array}$ \\
\hline Female MPs ${ }_{t-1}$ & $\begin{array}{l}-0.000 \\
(0.001)\end{array}$ & $\begin{array}{c}-0.000 \\
(0.001)\end{array}$ & $\begin{array}{l}-0.000 \\
(0.001)\end{array}$ & $\begin{array}{l}-0.000 \\
(0.001)\end{array}$ & $\begin{array}{l}-0.001 \\
(0.001)\end{array}$ & $\begin{array}{l}-0.000 \\
(0.001)\end{array}$ \\
\hline Social security transfers $t-1$ & $\begin{array}{c}-0.007^{* *} \\
(0.003)\end{array}$ & $\begin{array}{c}-0.006^{* *} \\
(0.003)\end{array}$ & $\begin{array}{c}-0.006^{* *} \\
(0.003)\end{array}$ & $\begin{array}{c}-0.006^{* *} \\
(0.003)\end{array}$ & $\begin{array}{c}-0.008^{* * * *} \\
(0.003)\end{array}$ & $\begin{array}{c}-0.008^{* * * *} \\
(0.003)\end{array}$ \\
\hline Left-Right ${ }_{t-1}$ & $\begin{array}{l}-0.002 \\
(0.002)\end{array}$ & $\begin{array}{l}-0.002 \\
(0.002)\end{array}$ & $\begin{array}{c}-0.002 \\
(0.002)\end{array}$ & $\begin{array}{l}-0.002 \\
(0.002)\end{array}$ & $\begin{array}{l}-0.004^{*} \\
(0.002)\end{array}$ & $\begin{array}{c}0.006 \\
(0.008)\end{array}$ \\
\hline Production workers (PW) & $\begin{array}{c}0.001 \\
(0.119)\end{array}$ & & & & & \\
\hline Sociocultural professionals (SCP) & $\begin{array}{c}0.007^{* * *} \\
(0.203)\end{array}$ & & & & & \\
\hline SCP-to-PW ratio & & $\begin{array}{c}\mathbf{0 . 0 8 0} \\
(0.025)\end{array}$ & 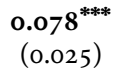 & $\begin{array}{c}0.075^{* * *} \\
(0.025)\end{array}$ & $\begin{array}{c}\mathbf{0 . 0 7 1} \mathbf{1}^{* * *} \\
(0.025)\end{array}$ & $\begin{array}{c}0.225^{* * * *} \\
(0.080)\end{array}$ \\
\hline Wy $y_{\text {ideo }}$ & & & $\begin{array}{l}-0.058 \\
(0.045)\end{array}$ & $\begin{array}{l}-0.057 \\
(0.045)\end{array}$ & $\begin{array}{c}-0.120^{* *} \\
(0.048)\end{array}$ & $\begin{array}{c}-0.125^{* * * *} \\
(0.048)\end{array}$ \\
\hline Wy $y_{\text {won }}$ & & & & 0.009 & 0.013 & 0.013 \\
\hline
\end{tabular}


TABLE 1. Continued

\begin{tabular}{|c|c|c|c|c|c|c|}
\hline VARIABLES & $\begin{array}{c}(1) \\
\text { Model } 1\end{array}$ & $\begin{array}{c}(2) \\
\text { Model } 2\end{array}$ & $\begin{array}{c}(3) \\
\text { Model } 3\end{array}$ & $\begin{array}{c}(4) \\
\text { Model } 4\end{array}$ & $\begin{array}{c}(5) \\
\text { Model } 5\end{array}$ & $\begin{array}{c}(6) \\
\text { Model } 6\end{array}$ \\
\hline & & & & (0.010) & $(0.010)$ & (0.010) \\
\hline Wy $y_{\text {lost }}$ & & & & $\begin{array}{c}-0.041^{* * *} \\
(0.013)\end{array}$ & $\begin{array}{c}-0.039^{* * *} \\
(0.012)\end{array}$ & $\begin{array}{c}0.097 \\
(0.083)\end{array}$ \\
\hline$W y_{g e o}$ & & & & & $\begin{array}{c}0.306^{* * * *} \\
(0.096)\end{array}$ & $\begin{array}{c}0.286^{* * *} \\
(0.096)\end{array}$ \\
\hline Losing $_{\mathrm{t}-1} \mathrm{x}$ Ratio & & & & & & $\begin{array}{c}-0.344^{* *} \\
(0.144)\end{array}$ \\
\hline Ratio x Left-Right ${ }_{t-1}$ & & & & & & $\begin{array}{l}-0.024^{*} \\
(0.014)\end{array}$ \\
\hline Losing $_{\mathrm{t}-1} \mathrm{x}$ Left-Right ${ }_{\mathrm{t}-1}$ & & & & & & $\begin{array}{l}-0.021 \\
(0.015)\end{array}$ \\
\hline Losing $_{\mathrm{t}-1} \mathrm{x}$ Ratio $\mathrm{x}$ Left-Right ${ }_{\mathrm{t}-1}$ & & & & & & $\begin{array}{l}0.056^{* *} \\
(0.027)\end{array}$ \\
\hline Constant & $\begin{array}{l}-0.511^{* * *} \\
(0.189)\end{array}$ & $\begin{array}{c}-0.352^{* *} \\
(0.159)\end{array}$ & $\begin{array}{l}-0.512^{* *} \\
(0.202)\end{array}$ & $\begin{array}{l}-0.343^{*} \\
(0.206)\end{array}$ & $\begin{array}{l}-0.100 \\
(0.217)\end{array}$ & $\begin{array}{l}-0.174 \\
(0.222)\end{array}$ \\
\hline $\begin{array}{l}\text { Observations } \\
\text { R-squared }\end{array}$ & $\begin{array}{c}345 \\
0.862\end{array}$ & $\begin{array}{c}345 \\
0.862\end{array}$ & $\begin{array}{c}345 \\
0.863\end{array}$ & $\begin{array}{c}345 \\
0.867\end{array}$ & $\begin{array}{c}345 \\
0.871\end{array}$ & $\begin{array}{c}345 \\
0.874\end{array}$ \\
\hline Number of groups & 23 & 23 & 23 & 23 & 23 & 23 \\
\hline
\end{tabular}

Standard errors in parentheses

${ }^{* * * *} \mathrm{p}<0.01,{ }^{* *} \mathrm{p}<0.05,{ }^{*} \mathrm{p}<0.1$ 
significant negative effect on the level of childcare expenditure, in line with the crowding out hypothesis, indicating that resources tend to be either allocated to social insurance or social investment. In most models, the effect of government ideology is not associated significantly with the outcome levels, in line with previous research that found an inconsistent effect of ideology in the development of post-industrial social policy (Bonoli, 2013; Bonoli and Reber, 2010). The coefficient for ideology, however, becomes a significant predictor of childcare expenditure levels when the effect of geographical diffusion of childcare expenditure is controlled for: For a unit increase in the Left-Right dimension, the expenditure for childcare is reduced by 0.004 percent of GDP.

For what concerns the effect of the size of occupational groups: the larger the share of socio-cultural professionals, the higher the demand for childcare services. A significant portion of socio-cultural professionals are women and younger and highly educated individuals, who generally prefer social investment over social consumption. Each unit percentage increase in the share of sociocultural professionals is associated with a rise in spending on childcare services by 0.007 percent of GDP. In contrast, the share of production workers does not significantly predict the level of childcare expenditure. Model 2 includes the ratio between SCP and PW instead of their overall shares, and the effect is positive and strong. Each unit increase in the SCP-to-PW ratio increases the expenditure for childcare services by 0.08 percent of GDP.

Model 3 includes the spatial lag for government ideological proximity, i.e. the average level of spending of every other country in the sample, weighted by the ideological distance between governments. The larger the ideological distance between the two governments, the larger the importance given to its value. The coefficient is negative, suggesting that policy decision in one country is followed by a similar decision in a country with an ideologically proximate government. The coefficient in model 3 is not significant, but it becomes significant once the control for geographic proximity is introduced in the specification, suggesting that policy diffusion takes place between countries with ideologically similar cabinets only as far as these countries are also geographically close. An increase of one percentage point in the average expenditure of ideological proximate governments is associated with a rise in expenditure by about 0.12 percent of GDP, indicating a strong diffusion between like-minded governments.

Models 4 and 5 include the indicators for political learning, i.e. the average expenditure levels in countries that recently experienced elections, weighted for the success and failure of incumbent coalitions. The larger the share of parties of the previous coalition that (do not) belong to the newly appointed cabinet, the larger the importance given to their expenditure choices. The coefficient of $W y_{\text {won }}$ is positive but not significant while the coefficient for $W y_{\text {lost }}$ is negative and significant. This suggests that success stories are not valued as much as fail- 


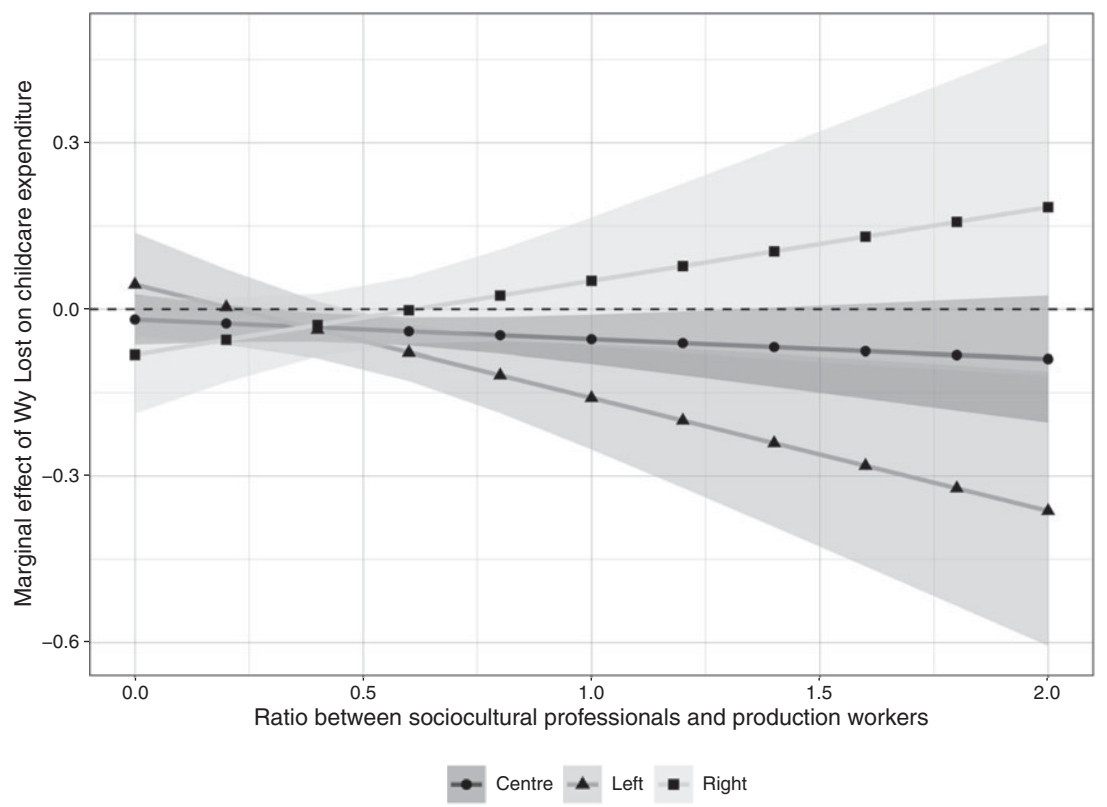

FIGURE 2. Marginal effects of Wy Lost for different SCP-to-PW ratios and for differentgovernment ideologies, with 95\% CINote: Left $=2.5$ on the left-right scale; Centre $=5.5$ on the left-right scale; Right $=8.5$ on the left right scale

ure stories. Such an effect is in line with research on cognitive biases that has consistently shown that negative and positive information is weighted differently, with higher value given to negative information (Kahneman and Tversky, 1979; Ito and Cacioppo, 2005; Rozin and Royzman, 2001), as well as with the findings in party politics research showing that political parties adjust their policy orientations according to shifts in public opinion only as long as such shifts are clearly disadvantageous for the party (Adams et al., 2004). Thus, $\mathrm{H}_{2}$ is supported but and $\mathrm{H}_{1}$ is rejected. The main effect on an increase of one percentage point in average spending level of governments that subsequently lost an election is associated with a reduction of spending by 0.04 percent of GDP. The estimated effect does not change once geographical proximity is controlled for.

Model 6 tests the scope conditions under which political learning should occur. Since it is not possible to infer meaningful conditional effects simply by looking at the significance of the interaction term (Brambor et al., 2006), in Figure 2 the conditional effects of political learning are plotted.

Figure 2 contains the average marginal effect of political learning for countries with different ratios between socio-cultural professionals and production workers, and different government orientations. For governments of right-wing and centrist ideologies, the slope of the marginal effects of $W y_{\text {lost }}$ is not significantly different from zero. Instead, for governments made by parties of the Left, 
the effect of political learning on the level of spending is strong and statistically significant: The effect of $W y_{\text {lost }}$ is close to zero when the size of production workers is much larger than socio-cultural professionals (values close to zero on the $\mathrm{x}$-axis) and becomes increasingly negative for larger shares of socio-cultural professionals, signalling an increasingly divided electorate.

To sum up, childcare expenditure levels were found to be positively associated with higher fertility rates, larger shares of socio-cultural professionals, the ratio between socio-cultural professionals and production workers, and negatively to the size of the expenditure for social security transfers. Left-wing governments were found to be associated with a higher childcare development when the influences of geographically proximate governments are controlled for. One of these influences is the behaviour of governments that is also ideologically proximate, as it appears that governments of similar ideology tend to make similar decisions with regards to childcare expenditure decisions. The analysis showed that these governments also learn from the negative political consequences of their foreign counterparts that have recently governed: In particular, governments of the Left with a divided electorate tend to reduce their expenditure levels whenever a foreign incumbent that previously did so loses the elections.

\section{Conclusions}

Political explanations of social policy development are central in the comparative politics literature on the welfare state, especially with regards to the expansion and retrenchment of benefits. Early theories posited that a large working-class with homogenous preferences for state intervention represented by left-wing parties in government was central to welfare state development. More recently, evidence has shown that the role of politics in welfare state development has changed. Post-industrial societies brought about new social risks and new strategies to cope with them, i.e. social investment policies. These new strategies imply an expansion of instruments that compete with existing entitlements, creating new conflicts, and fragmenting the historical constituencies of political parties.

I have argued in this paper that this situation generates a political dilemma for the parties whose historical core constituencies are losing importance and must attract new voters. In doing so, these parties may have an interest in the expansion of social investment but lack complete information on the political consequences of such a course of action. I hypothesized that as a consequence of such lack of information, governments learn from their foreign counterparts' decisions and their electoral consequences.

To test the political learning mechanism, I modelled childcare expenditure levels in 23 welfare states using a set of dynamic spatial autoregressive models that allow for interdependencies between units to be included in the regression. 
I hypothesised that incumbent cabinet coalitions which increased levels of expenditure and were rewarded or sanctioned in a subsequent election should be respectively associated with higher or lower levels of spending in other units. The results of the analysis do not support the hypothesis that higher levels of expenditure of successful cabinets are positively associated with expenditure levels in other units but support the hypothesis of governments learning from the electoral failures of foreign counterparts.

As predicted, political learning significantly affects childcare expenditure only when a relevant political dilemma has the conditions to emerge, i.e. when the importance of groups preferring social consumption - production workers is declining and that of groups with a preference for social investment socio-cultural professionals - is growing. The effect is significant only for the parties on the left of the political spectrum, whose electorate is particularly divided between these two groups.

Adopting a policy diffusion framework, this study contributed to the literature on the determinants of the development of social investment investigating it from a novel angle and proposing a link between institutional and political explanations of policy development. Despite being widely advocated at the supranational level and in academia as a productive instrument to protect individuals and families in post-industrial societies from new social risks, social investment policies are developing slowly in Europe. The findings of this study show that such a weak diffusion may be due partly to the uncertainty that parties in the government coalitions have regarding the political consequences implied by a trade-off between new policies and existing entitlements. More broadly, the implications of these findings indicate that political actors may moderate the feedback effect of existing institutions via the perception that they have of possible political consequences, suggesting a channel through which institutional feedback influences the development of new policies. This general conclusion is, however, a plausible claim made on the findings of this study but it was not empirically tested and contains an element of speculation. Future research should explore more carefully the role of political moderation and use more accurate measures of the perception that political actors have of the environment in which they operate.

Supplementary material information: the dataset and scripts for the replication of the analysis will be made available upon request of the editor, the reviewers, or for publication.

\section{Acknowledgements}

Earlier versions of this paper were presented at the ESPAnet 2019 in Stockholm and at the 11 th Nordwel Summer School in Bremen. I am grateful for the participants' constructive input. Moreover, I wish to thank Tobias Böger, Julian Garritzmann, Eloisa Harris, Johannes 
Huinink, Carina Schmitt and two anonymous reviewers for their valuable feedback, and Hanne Gaukel for her helpful assistance. Funded by Deutsche Forschungsgemeinschaft (DFG) Projektnummer 374666841 - SFB 1342.

\section{Competing interests}

The author declares none.

\section{Supplementary material}

To view supplementary material for this article, please visit https://doi.org/10. $1017 /$ So047279421000908

\section{Note}

1 The countries included in the analysis are Austria, Belgium, Switzerland, Czech Republic, Germany, Denmark, Spain, Estonia, Finland, France, United Kingdom, Greece, Hungary, Ireland, Iceland, Italy, Netherlands, Norway, Poland, Portugal, Slovak Republic, Slovenia, and Sweden.

\section{References}

Abel, D. (2019), 'The diffusion of climate policies among German municipalities', Journal of public policy. 1-26.

Abou-Chadi, T. and Wagner, M. (2019), 'The electoral appeal of party strategies in postindustrial societies: when can the mainstream left succeed?', The Journal of Politics 81(4): $1405-1419$.

Achen, C. (2000), 'Why Lagged Dependent Variable Can Suppress the Explanatory Power of the Independent Variable'. Political Methodology Section of the American Political Science Association Annual Meeting. UCLA.

Adam, A. and Ftergioti, S. (2019), 'Neighbors and friends: How do European political parties respond to globalization?', European Journal of Political Economy 59: 369-384.

Adams, J., Bernardi, L. and Wlezien, C. (2020), 'Social welfare policy outputs and governing parties' left-right images: Do voters respond?', The Journal of Politics 82(3): 1161-1165.

Adams, J., Clark, M., Ezrow, L. and Glasgow, G. (2004), 'Understanding change and stability in party ideologies: do parties respond to public opinion or to past election results?', British Journal of Political Science 34(4): 589-610.

Adams, J., Clark, M., Ezrow, L. and Glasgow, G. (2006), 'Are niche parties fundamentally different from mainstream parties? The causes and the electoral consequences of Western European parties' policy shifts, 1976-1998', American journal of political science 50(3): 513-529.

Anselin, L., Le Gallo, J. and Jayet, H. (2008), 'Spatial panel econometrics', The econometrics of panel data. Heidelberg: Springer, pp.625-66o.

Armingeon, K. and Bonoli, G. (2007), The politics of post-industrial welfare states: adapting post-war social policies to new social risks: Routledge.

Armingeon, K., Wenger, V., Wiedemeier, F., Isler C., Knöpfel L.,Weisstanner, D. and Engler, S. (2019), Comparative Political Data Set 1960-2017. Bern: Institute of Political Science, University of Berne.

Beck, N. and Katz, J.N. (2011), 'Modeling dynamics in time-series-cross-section political economy data', Annual Review of Political Science 14: 331-352. 
Beramendi, P., Häusermann, S., Kitschelt, H. and Kriesi, H. (eds.) (2015), The politics of advanced capitalism. New York: Cambridge University Press.

Bernardi, L. and Adams, J. (2019), 'Does government support respond to governments' social welfare rhetoric or their spending? An analysis of government support in Britain, Spain and the United States', British Journal of Political Science 49(4): 1407-1429.

Böhmelt, T., Ezrow, L., Lehrer, R., Schleiter, P. and Ward, H. (2017), 'Why dominant governing parties are cross-nationally influential', International Studies Quarterly 61(4): 749-759.

Böhmelt, T., Ezrow, L., Lehrer, R. and Ward, H. (2016), 'Party policy diffusion', American Political Science Review 110(2): 397-410.

Bonoli, G. (2005), 'The politics of the new social policies: providing coverage against new social risks in mature welfare states', Policy \& politics 33(3): 431-449.

Bonoli, G. (2013), The origins of active social policy: Labour market and childcare policies in a comparative perspective: Oxford University Press.

Bonoli, G. and Reber, F. (2010), 'The political economy of childcare in OECD countries: Explaining cross-national variation in spending and coverage rates', European Journal of Political Research 49(1): 97-118.

Bouget, D., Frazer, H., Marlier, E., Sabato, S. and Vanhercke, B. (2015), Social Investment in Europe. A study of national policies. Brussels: European Commission.

Brambor, T., Clark, W.R. and Golder, M. (2006), 'Understanding interaction models: Improving empirical analyses', Political analysis, 63-82.

Braun, D. and Gilardi, F. (2006), 'Taking 'Galton's problem' seriously: Towards a theory of policy diffusion', Journal of theoretical politics, 18(3): 298-322.

Busemeyer, M.R. and Garritzmann, J.L. (2017), 'Public opinion on policy and budgetary tradeoffs in European welfare states: evidence from a new comparative survey', Journal of European Public Policy 24(6): 871-889.

Busemeyer, M.R., Garritzmann, J.L. and Neimanns, E. (2015), Public opinion towards policy trade-offs: Investigating attitudes on social investment and compensatory welfare policies with a new comparative survey. Workshop citizens in changing welfare states: Pressures, frames, and feedback, University of Gothenburg, Gothenburg.

Busemeyer, M.R. and Neimanns, E. (2017), 'Conflictive preferences towards social investments and transfers in mature welfare states: The cases of unemployment benefits and childcare provision', Journal of European Social Policy 27(3): 229-246.

Butler, D. M., Volden, C., Dynes, A. M. and Shor, B. (2017), 'Ideology, learning, and policy diffusion: Experimental evidence', American journal of political science 61(1): 37-49.

Chung, H. and Meuleman, B. (2017), 'European parents' attitudes towards public childcare provision: The role of current provisions, interests and ideologies', European Societies 19(1): 49-68.

Döring, H. and Manow, P. (2019), 'Parliament and government composition database (ParlGov)', An infrastructure for empirical information on parties, elections and governments in modern democracies. Version 12(10).

Dunlop, C.A. and Radaelli, C.M. (2013), 'Systematising policy learning: From monolith to dimensions', Political studies 61(3): 599-619.

Elhorst, J.P. (2014), Spatial econometrics: from cross-sectional data to spatial panels: Springer.

Emmenegger, P., Häusermann, S., Palier, B. and Seeleib-Kaiser, M. (2012), 'How rich countries cope with deindustrialization', The Age of Dualization: The Changing Face of Inequality in Deindustrializing Societies. 304-320.

Esping-Andersen, G. (2002), 'A child-centred social investment strategy', Why we need a new welfare state. 26-67.

Esping-Andersen, G. (2009), Incomplete revolution: Adapting welfare states to women's new roles: Polity.

ESS (2018), European Social Survey Cumulative File, ESS 1-8 (2018). Data file edition 1.o. NSD Norwegian Centre for Research Data, Norway - Data Archive and distributor of ESS data for ESS ERIC. 
Fleckenstein, T. (2011), 'The politics of ideas in welfare state transformation: Christian democracy and the reform of family policy in Germany', Social Politics 18(4): 543-571.

Franzese, R.J. and Hays, J.C. (2007), 'Spatial econometric models of cross-sectional interdependence in political science panel and time-series-cross-section data', Political analysis 15(2): 140-164.

Franzese Jr, R.J. and Hays, J.C. (2008), 'Interdependence in comparative politics: Substance, theory, empirics, substance'. Comparative Political Studies, 41(4-5): 742-780.

Garritzmann, J.L., Busemeyer, M.R. and Neimanns, E. (2018), 'Public demand for social investment: new supporting coalitions for welfare state reform in Western Europe?', Journal of European Public Policy 25(6): 844-861.

Gilardi, F. (2010), 'Who learns from what in policy diffusion processes?', American journal of political science 54(3): 650-666.

Gilardi, F. (2012), 'Transnational diffusion: Norms, ideas, and policies', Handbook of international relations 2: 453-477.

Gilardi, F. and Wasserfallen, F. (2019), 'The politics of policy diffusion', European Journal of Political Research 58(4): 1245-1256.

Gleditsch, K. and Ward, M.D. (2008), Spatial regression models: Sage Publications Inc.

Graham, E.R., Shipan, C.R. and Volden, C. (2013), 'The diffusion of policy diffusion research in political science', British Journal of Political Science. 673-701.

Häusermann, S. (2010), The politics of welfare state reform in continental Europe: Modernization in hard times: Cambridge University Press.

Häusermann, S. (2018), 'Institutional Legacies and Party Competition', Welfare Democracies and Party Politics: Explaining Electoral Dynamics in Times of Changing Welfare Capitalism. 150.

Häusermann, S. and Kriesi, H. (2015), 'What do voters want? Dimensions and configurations in individual-level preferences and party choice', The politics of advanced capitalism. 202-230.

Häusermann, S., Kurer, T. and Schwander, H. (2014), 'High-skilled outsiders? Labor market vulnerability, education and welfare state preferences', Socio-Economic Review 13(2): 235-258.

Häusermann, S., Pinggera, M., Ares, M. and Enggist, M. (2019), 'The Limits of Solidarity. Changing welfare coalitions in a transforming European party system. ', Paper prepared for the International Conference of Europeanists (CES), June 20-22 in Madrid.

Hook, J.L. (2015), 'Incorporating 'class' into work-family arrangements: Insights from and for Three Worlds', Journal of European Social Policy 25(1): 14-31.

Ito, T. and Cacioppo, J. (2005), 'Variations on a human universal: Individual differences in positivity offset and negativity bias', Cognition \& Emotion 19(1): 1-26.

Kahneman, D. and Tversky, A. (1979), 'Prospect Theory: An Analysis of Decision under Risk', Econometrica 47(2): 263-292.

Karreth, J., Polk, J.T. and Allen, C.S. (2013), 'Catchall or catch and release? The electoral consequences of social democratic parties' march to the middle in Western Europe', Comparative Political Studies 46(7): 791-822.

Kim, Y.Y. and Choi, Y.J. (2020), 'Does social protection crowd out social investment?', Policy and Society 39(2): 208-225.

Korpi, W. (2000), 'Faces of inequality: Gender, class, and patterns of inequalities in different types of welfare states', Social Politics: international studies in gender, state \& society $7(2)$ : 127-191.

Lewis, J., Knijn, J. T., Martin, J. and Ostner, J. T. (2008), Patterns of Development in Work/ Family Reconciliation Policies for Parents in France, Germany, the Netherlands, and the UK in the 2000s. Social Politics: International Studies in Gender, State and Society, 15, 261-286.

Linos, K. (2013), The democratic foundations of policy diffusion: How health, family, and employment laws spread across countries: Oxford University Press. 
Mallinson, D.J. and Hannah, A.L. (2020), 'Policy and Political Learning: The Development of Medical Marijuana Policies in the States', Publius: The Journal of Federalism.

May, P.J. (1992), 'Policy learning and failure', Journal of public policy 12(4): 331-354.

McDermott, R. (2001), 'The psychological ideas of Amos Tversky and their relevance for political science', Journal of theoretical politics 13(1): 5-33.

Meseguer, C. (2003), 'Learning and economic policy choices: a Bayesian approach'.

Meseguer, C. (2004), 'What role for learning? The diffusion of privatisation in OECD and Latin American countries', Journal of public policy. 299-325.

Meseguer, C. (2005), 'Policy learning, policy diffusion, and the making of a new order', The Annals of the American Academy of Political and Social Science 598(1): 67-82.

Morel, N. and Palier, B. (2011), Towards a social investment welfare state?: Ideas, policies and challenges: Policy Press.

Morgan, K.J. (2013), 'Path shifting of the welfare state: Electoral competition and the expansion of work-family policies in Western Europe', World politics 65(1): 73-115.

Natali, D. (2002), 'La ridefinizione del welfare state contemporaneo: la riforma delle pensioni in Francia e in Italia'.

Neimanns, E. (2021), 'Preferences, vote choice, and the politics of social investment: Addressing the puzzle of unequal benefits of childcare provision', Journal of Social Policy. 1-20.

Nelson, M. and Giger, N. (2019), 'Social investment by popular demand? The electoral politics of employment-centered family policy', Comparative European Politics 17(3): 426-446.

OECD (2018a), OECD Economic Outlook No. 103. OECD Economic Outlook: Statistics and Projections Paris: OECD.

OECD (2018b), Social Expenditure: Aggregated data. OECD Social Expenditure Statistics Paris: OECD.

Oesch, D. (2006), 'Coming to grips with a changing class structure: An analysis of employment stratification in Britain, Germany, Sweden and Switzerland', International Sociology 21(2): 263-288.

Pacheco, J. (2012), 'The social contagion model: Exploring the role of public opinion on the diffusion of antismoking legislation across the American states', The Journal of Politics 74(1): 187-202.

Pacheco, J. and Maltby, E. (2017), 'The role of public opinion-does it influence the diffusion of ACA decisions?', Journal of Health Politics, Policy and Law 42(2): 309-340.

Palier, B. (2010), A long goodbye to Bismarck? The politics of welfare reform in continental Europe: Amsterdam Univ. Press.

Palier, B. and Thelen, K. (2010), 'Institutionalizing dualism: Complementarities and change in France and Germany', Politics \& Society 38(1): 119-148.

Pierson, P. (1994), Dismantling the welfare state?: Reagan, Thatcher and the politics of retrenchment: Cambridge University Press.

Plümper, T. and Neumayer, E. (2010), 'Model specification in the analysis of spatial dependence', European Journal of Political Research 49(3): 418-442.

Plümper, T., Troeger, V.E. and Manow, P. (2005), 'Panel data analysis in comparative politics: Linking method to theory', European Journal of Political Research 44(2): 327-354.

Rozin, P. and Royzman, E.B. (2001), 'Negativity bias, negativity dominance, and contagion', Personality and social psychology review 5(4): 296-320.

Rueda, D. (2005), 'Insider-outsider politics in industrialized democracies: The challenge to social democratic parties', American Political Science Review 99(1): 61-74.

Schleiter, P., Böhmelt, T., Ezrow, L. and Lehrer, R. (2021), 'Social Democratic Party Exceptionalism and Transnational Policy Linkages', World politics. 1-33.

Schwander, H. (2018), 'Electoral demand, party competition and family policy: The politics of a new policy field'. In P. Manow, B. Palier and H. Schwander (eds.), Welfare democracies and party politics: Explaining electoral dynamics in times of changing welfare capitalism, Oxford: Oxford University Press, pp.197-224. 
Schwander, H. and Häusermann, S. (2013), 'Who is in and who is out? A risk-based conceptualization of insiders and outsiders', Journal of European Social Policy 23(3): 248-269.

Shipan, C.R. and Volden, C. (2008), 'The mechanisms of policy diffusion', American journal of political science 52(4): 840-857.

Simmons, B.A., Dobbin, F. and Garrett, G. (2006), 'Introduction: The international diffusion of liberalism', International organization. 781-810.

Tversky, A. and Kahneman, D. (1974), 'Judgment under uncertainty: Heuristics and biases', science 185(4157): 1124-1131.

Van Lancker, W. (2013), 'Putting the child-centred investment strategy to the test: Evidence for the EU27', European Journal of Social Security 15(1): 4-27.

Volden, C. (2006), 'States as policy laboratories: Emulating success in the children's health insurance program', American journal of political science 50(2): 294-312.

Weyland, K. (2009), Bounded rationality and policy diffusion: Social sector reform in Latin America: Princeton University Press.

Weyland, K. (2012), 'The Arab Spring: Why the surprising similarities with the revolutionary wave of 1848?', Perspectives on Politics 10(4): 917-934.

Wilkins, A.S. (2018), 'To lag or not to lag?: Re-evaluating the use of lagged dependent variables in regression analysis', Political Science Research and Methods 6(2): 393.

Williams, L.K. (2015), 'It's all relative: Spatial positioning of parties and ideological shifts', European Journal of Political Research 54(1): 141-159.

Williams, L.K. and Whitten, G.D. (2015), 'Don't stand so close to me: Spatial contagion effects and party competition', American Journal of Political Science 59(2): 309-325.

World Bank (2019a), Female Labour Force Participation (Share of Total Labour Force). World Development Indicators database. New York: World Bank.

World Bank (2019b), GDP per capita, PPP (constant 2017 international \$). World Development Indicators database. New York: World Bank.

World Bank (2019c), Total Fertility Rate (Number of Births per Woman). World Development Indicators database. New York: World Bank. 